\title{
CUSTOMER ENGAGEMENT AKUN INSTAGRAM DALAM MENINGKATKAN IMPULSIVE BUYING
}

\author{
Hafizh Abdurrahman Nabil ${ }^{1}$, Witri Cahyati ${ }^{2}$ \\ ${ }^{1,2}$ Universitas Sangga Buana YPKP Bandung \\ ${ }^{1}$ korespondensi : hafizhabdurrahman.ha@gmail.com
}

\begin{abstract}
This study discusses customer engagement on Instagram accounts in increasing impulsive buying on the Dudimsum brand in the city of Bandung. This study was to determine the customer engagement of Instagram accounts in increasing impulsive buying on the Dudimsum brand in the city of Bandung. The purpose of this study was to find out what media Dudimsum's customer engagement used in increasing impulsive buying, to find out customer engagement posts on Dudimsum's Instagram in increasing impulsive buying and to find out why Dudimsum's customers were willing to voluntarily create content on Instagram @ Dudimsum. This study uses a qualitative method with the type of case study research. perform data collection techniques by observation, in-depth interviews (in-depth interviews) and documentation. The results of this study are. (1) The customer engagement media used by Dudimsum in increasing impulsive buying is Instagram social media. (2) Customer engagement postings on Dudimsum's Instagram in increasing impulsive buying in the form of content and programs for updating feed posts and stories, prioritizing product exposure or displaying products with attractive and innovative displays, holding promos and give aways. information about products and brands is presented in full and in detail so that information about the Dudimsum brand can be accessed easily and quickly. (3) Dudimsum always tries to provide the best taste and service. Dudimsum tries its best to always respond and repost posts or stories via Instagram, so that customers will feel appreciated.
\end{abstract}

Keywords: Customer engagement, impulsive buying, new media.

\begin{abstract}
ABSTRAK
Penelitian ini membahas tentang customer engagement akun instagram dalam meningkatkan impulsive buying pada brand Dudimsum di kota Bandung. Penelitian ini untuk mengetahui customer engagement akun Instagram dalam meningkatkan Impulsive buying pada brand Dudimsum di kota Bandung. Tujuan penelitian ini adalah untuk mengetahui media apa yang digunakan customer engagement Dudimsum dalam meningkatkan impulsive buying, untuk mengetahui postingan customer engagement di Instagram Dudimsum dalam meningkatkan impulsive buying dan untuk mengetahui alasan pelanggan Dudimsum bersedia membuat konten di Instagram @Dudimsum secara sukarela. Penelitian ini menggunakan metode kualitatif dengan jenis penelitian studi kasus. melakukan teknik pengumpulan data dengan observasi, wawancara mendalam (indepth interview) dan dokumentasi. Hasil penelitian ini adalah. (1) Media customer engagement yang digunakan Dudimsum dalam meningkatkan impulsive buying adalah media sosial Instagram.(2) Postingan customer engagement di Instagram Dudimsum dalam meningkatkan impulsive buying berupa konten dan programprogram pembaruan feed postingan dan instastory, mengutamakan exposure produk atau menampilkan produk dengan tampilan yang menarik dan inovatif, mengadakan promo-promo dan give away. informasi mengenai produk dan brand disajikan secara lengkap dan detail sehingga informasi mengenai brand Dudimsum dapat langsung terakses dengan mudah dan cepat. (3) Dudimsum selalu berusaha memberikan cita rasa dan pelayanan terbaik. Dudimsum berusaha semaksimal mungkin untuk selalu merespon dan merepost postingan atau instastory melalui Instagram, sehingga customer akan merasa di hargai.
\end{abstract}

Kata kunci: Customer engagement, impulsive buying, new media.

\section{PENDAHULUAN}

\section{Latar Belakang Penelitian}

Konsumen di era digital menginginkan pelayanan yang serba instan dan praktis, banyak faktor dan aspek yang mempengaruhi konsumen untuk berbelanja dan membeli suatu produk pada media sosial tanpa sadar dan tanpa mempertimbangkan untuk membeli produk tersebut. Maka dari itu perusahaan atau brand harus terus up to date melalui media sosial agar informasi dan pesan mengenai produk dan brand tersampaikan dengan cepat dan efektif. Dudimsum telah 
memiliki 13.288 followers pada akun Instagram. Ternyata masih ditemukan beberapa kendala dalam pemanfaatan media sosial, diantaranya konten yang kurang menarik, postingan customer engagement $\mathrm{di}$ instagram Dudimsum dan lain sebagainya.

Banyak faktor dan aspek yang mempengaruhi konsumen untuk belanja atau membeli suatu produk, Saat berbelanja, tanpa sadar kebanyakan individu melalui beberapa pertimbangan sebelum akhirnya memutuskan untuk membeli produk tersebut atau tidak. Ada banyak hal yang menjadi pertimbangan mulai dari akses yang mudah, tampilan toko, harga yang terjangkau, promosi yang menarik, komunikasi yang mudah dimengeti, riview dari konsumen, pelayanan yang berkualitas, waktu pengiriman, informasi, ketersediaan, kualitas produk, kebutuhan pribadi, faktor budaya dan sosial. Sebagai pebisnis, baik bisnis offline maupun online khususnya dalam bidang kuliner, memahami faktorfaktor yang mempengaruhi konsumen untuk membeli dapat membantu mengembangkan strategi untuk menjangkau konsumen dan meningkatkan penjualan.

Media sosial berpengaruh sangat besar terhadap penjualan suatu produk, penggunaan media sosial secara tepat akan menarik para konsumen untuk membeli produk atau jasa. Mengingat perkembangannya yang sangat cepat, media sosial dapat menjadi media paling strategis bagi pemasaran sebuah merek atau brand suatu brand atau perusahaan untuk menjangkau konsumen kedepannya.
Perusahaan dapat mengunggah berbagai konten dan informasi melalui media sosial untuk meningkatkan penjualan suatu produk dengan berbagai konten dan metode yang menarik danmenjual. Dari sekian banyak media sosial yang muncul, pada penelitian ini memilih Instagram sebagai media untuk digunakan sebagai sarana berpromosi. Pencarian informasi yang sudah semakin mudah melalui berbagai aplakasi media sosial memudahkan dalam menentukan pengambilan keputusan dalam berbelanja di jejaring sosial. Informasi yang dikumpulkan bisa berupa harga, merek, kualitas produk, spesifikasi barang, bentuk produk, riview produk, dan lain sebagainya. Selanjutnya informasi tersebut akan menjadi bahan pertimbangan bagi konsumen dalam menentukan pembelian suatu produk. Penggunaan media sosial, terutama Instagram, dapat digunakan dengan mudah oleh para pelaku bisnis khususnya bidang kuliner untuk mempromosikan dan menginformasikan brand dan produk melalui konten-konten yang dijadikan konsep untuk mengangkat popularitas brand dan produk itu sendiri, agar dapat bertahan terhadap persaingan.

Salah satu usaha dalam mempengaruhi konsumen untuk membeli produk adalah dengan meningkatkan hubungan atara konsumen dan brand melalui customer engagement dimana customer engagement dalah hal yang sangat penting. Customer engagement adalah proses untuk mengembangkan, memelihara dan melindungi konsumen agar terus melakukan hubungan dengan perusahaan sehingga konsumen bukan hanya menjadi pembeli perusahaan bahkan melebihi dari sekedar 
pembeli yaitu menjadi pemasar bagi perusahaan [1]. Hubungan yang terjalin dengan baik antara produsen dan konsumen akan mengikat customer untuk terus memilih produk kita secara berkala. Ketika berhasil menciptakan customer engagement dalam jangka panjang, pelanggan akan merasa puas dengan pelayanan yang brand telah berikan. Salah satu indikator keterlibatan pelanggan yangberhasil adalah loyalitas customer menjadi semakin meningkat pada produk dan layanan jasa kita dengan mengedepankan customer engagement. Customer engagement telah menjadi hal penting dalam kelangsungan usaha dan telah menarik perhatian para praktisi dan akademisi [2]. Hal ini karena pertumbuhan internet dari teknologi Web 2.0 sebagai platform yang efektif untuk interaksi pelanggan. Khususnya, pada lingkungan online telah menyebabkan berbagai saluran media baru atau new media seperti media sosial yang memungkinkan pelanggan berinteraksi secara mudah dengan perusahaan atau pelanggan lain, karena sifatnya yang dua arah atau (two way trafict) dimana pelanggan dapat merespon langsung pesan atau informasi yang disampaikan komunikan atau brand melalui media sosial.

Dans Paulson (2009) menjabarkan bahwa engagement adalah segala usaha untuk melibatkan customer di dalam interaksi emosional antara perusahaan dan customernya [3]. Biasanya di dalam bisnis interaksi dengan customer hanya dipandang sebagai sebuah proses belaka, tidak sebagai hubungan jangka panjang. Customer engagement adalah perilaku yang membuat konsumen dapat memberikan voluntary contribution (kontribusi yang bersifat sukarela) bagi brand sebuah perusahaan, dimana kontribusi tersebut bukan hanya sebatas proses transaksi (pembelian) saja [4]. Kontribusi yang diberikan oleh konsumen adalah feedback, saran ataupun ide, kontribusi tersebut dapat berupa WOM (word of mouth), rujukan dan lain-lain yang dapat meningkatkan perolehan, penyimpanan dan wallet share perusahaan [5]. Menurut Time, Inc dalam Strauss \& Frost (2014) Customer engagement memiliki tiga pilar yaitu:

a. Content engagement adalah bagaimana brand dapat mengelola konten media sosial mereka agar pelanggan dapat tertarik dan mau ikut bergabung dan berinteraksi, konten bagi content engagement dalam media sosial sangat penting karena konten adalah hal pertama yang dilihat oleh pelanggan.

b. Media engagement adalah media apa yang akan digunakan untuk mem-posting konten yang sudah ada, karena jika media sosial yang dipilih tidak sesuai dengan konten yang menarik, maka akan menjadi sia-sia.

c. Engagement marketing activities adalah halhal yang digunakan untuk menarik penonton ke media melalui konten. Engagement marketing activites yang menarik membantu pelanggan membangun asosiasi personal dengan brand, seperti saat pelanggan dapat mengkostumasi produk mereka, memberikan komentar pada unggahan, membagikan unggahan tersebut ke teman- temannya, dan masih banyak lagi.Keterlibatan pelanggan di media sosial 
dapat mengambil banyak bentuk dan dapat didefinisikan sebagai tindakan online apa pun yang dilakukan pelanggan terkait dengan bisnis. Bentuk online engagement dapat berupa berlangganan atau subscribe, membeli, tanda suka atau like, membagikan suatu konten kepada teman atau share, komentar, blog atau posting blog, dan lain sebagainya. Contoh tindakan paling sederhana dari online customer engagement adalah ketika seseorang berkunjung ke halaman web atau media sosial suatu perusahaan. Oleh karena itu, perusahaan perlu fokus untuk mengarahkan traffic ke halaman web mereka, dan yang paling penting yaitu, menjaga pelanggan untuk tetap berkunjung atau terikat di situs web perusahaan untuk waktu yang lebih lama [6].

Banyak brand atau perusahaan melakukan kegiatan customer engagement melalui pendekatan komunikasi new media, khususnya media sosial Instagram. Dengan menggunakan berbagai usaha melalui konten yang disampaikan melalui media sosial Instagram untuk meningkatkan penjualan produk. Beberapa contoh kegiatan customer engagement yang dilakukan oleh brand kuliner Warunk Upnormal dan Ngikan. kegiatan customer engagement brand kuliner Warunk Upnormal pada bulan Maret 2021 dan konten/program giveaway pada bulan Desember 2020, selain itu kegiatan customer engagement brand Ngikan pada bulan September dan bulan Desember tahun 2020 melalui media sosial Instagram dengan menggunakan pendekatan teori new media. Warunk Upnormal dan Ngikan memberikan kemudahan dalam berinteraksi antara brand dengan konsumennya melalui akun media sosial Instagram, dan kebebasan dalam memberikan kritik dan saran untuk kebaikan perusahaan kedepannya. Selain itu Warunk Upnormal dan Ngikan melakukan promo dan giveaway untuk melibatkan customer dalam kegiatan pada media sosial Instagram untuk menjaga hubungan dengan brand atau perusahaan sehingga konsumen bukan hanya menjadi pembeli tetapi melebihi dari sekedar pembeli yaitu menjadi pemasar bagi perusahaan. Berikut contoh kegiatan customer engagement yang dilakukan oleh konsumen secara sukarela dengan beberapa kegiatan promosi dan giveaway pada akun Instagram Warunk Upnormal dan Ngikan.

Pada penelitian ini, brand atau perusahaan yang diteliti adalah Dudimsum. Dudimsum adalah salah satu pelaku bisnis yang bergerak di bidang kuliner didirikan oleh Muhammad Bani Bastian pada bulan april tahun 2017. Dudimsum menghadapi sebuah masalah dimana pada bulan Mei 2020 Dudimsum mengalami Keuntungan terendah yaitu sebesar Rp. 18.944.500. Dimana keuntungan tertinggi Dudimsum di tahun 2020 terjadi pada bulan November yaitu mencapai Rp.87.518.500. Hal ini disebabkan karena pada bulan Mei pemda kota Bandung melarang pelaku usaha kuliner untuk memperbolehkan konsumen makan di tempat atau dine in. Selain alasaan tersebut penurunan laba ini menurut Muhammad Bani Bastian karena kurang maksimalnya pemanfaatann media sosial sebagai sarana promosi. Hal ini juga menjadi alasan menurunnya laba di bulan April, Juli dan 
bulan September Tahun 2020 walaupun Dudimsum telah memiliki 13.288 followers pada akun Instagram. Ternyata masih ditemukan beberapa kendala dalam pemanfaatan media sosial, diantaranya konten yang kurang menarik, penjadwalan feed Instagram untuk memberikan informasi mengenai brand dan produk yang tidak konsisten, juga kurangnya interaksi dengan konsumen di akun Instagramnya. Hal ini sudah dikonfirmasi dengan Muhammad Bani Bastian. mengakibatkan menurunnya insight pada akun Instagram, dengan followers diatas Dudimsum menurut Muhammad Bani Bastian belum maksimal dalam penggunaannya.

Dari uraian diatas, Dalam penelitian ini, peneliti mengambil judul Customer engagement Akun Instagram Dalam Meningkatkan Impulsive buying (Pendekatan Kualitatif Studi Kasus Customer Engagement Akun Instagram Dalam Meningkatkan Impulsive buying Pada Dudimsum di Kota Bandung).

\section{Rumusan Masalah}

Berdasarkan latar belakang diatas, masalah dalam penelitian ini yaitu, bagaimana customer engagement akun Instagram dalam meningkatkan impulsive buying?

\section{Identifikasi Masalah}

Berdasarkan rumusan masalah yang ada, identifikasi masalah pada penelitian ini yaitu pertama media apa yang digunakan customer engagement Dudimsum dalam meningkatkan impulsive buying, yang kedua bagaimana postingan customer engagement di Instagram Dudimsum dalam meningkatkan impulsive buying dan ketiga adalah mengapa pelanggan Dudimsum bersedia membuat konten di Instagram @Dudimsum?

\section{State of The Art}

Ada beberapa penelitian terdahulu yang memiliki kaitannya dengan masalah yang dibahas, pertama adalah strategi marketing public relations melalui media instagram @ traveloka dalam meningkatkan customer engagement. Hana rufaidah larassati, jakarta barat, dki Jakarta. Kedua Pengaruh daya tarik iklan online shop terhadap pembelian impulsive (impulsive buying) pada mahasiswa fakultas psikologi universitas islam negri (uin) maulana maliki ibrahim malang. Rizka maulidya, metode kuantitatif, malang, jawa timur.

\section{METODE PENELITIAN}

\section{Pendekatan Penelitian}

Pendekatan penelitian yang digunakan dalam penelitian ini adalah pendekatan kualitatif studi kasus. Penelitian kualitatif adalah tradisi tertentu dalam ilmu pengetahuan sosial yang secara fundamental bergantung dari pengamatan pada manusia, baik dalam kawasannya maupun dalam peristilahannya [7]. Sedangkan studi kasus menyatakan pendekatan studi kasus merupakan penelitian mengenai manusia (dapat suatu kelompok, organisasi maupun individu), peristiwa, latar secara mendalam, tujuan dari penelitian ini mendapatkan gambaran yang mendalam tentang suatu kasus yang sedang diteliti [8].

Pengumpulan datanya diperoleh dari 
wawancara, observasi, dan dokumentasi.

Studi kasus menurut, Nursalam (2016) adalah merupakan penelitian yang mencakup pengkajian bertujuan memberikan gambaran secara mendetail mengenai latar belakang, sifat maupun karakter yang ada dari suatu kasus, dengan kata lain bahwa studi kasus memusatkan perhatian pada suatu kasus secara intensif dan rinci [9]. Penelitian dalam metode dilakukan secara mendalam terhadap suatu keadaan atau kondisi dengan cara sistematis mulai dari melakukan pengamatan, pengumpulan data, analisis informasi dan pelaporan hasil.

Adapun alasan peneliti dalam menggunakakn metode penelitian kualitatif dengan pendekatan studi kasus adalah untuk mendapatkan gambaran yang mendalam dan terperinci tentang suatu kasus yang sedang diteliti mengenai fakta dalam suatu objek. Dalam hal ini, customer engagement akun Instagram dalam meningkatkan impulsive buying pada Dudimsum di kota Bandung.

Kedalam data dalam penelitian ini merupakan hal yang menjadi pertimbangan utama dalam model penelitian ini. Untuk membedah lebih dalam mengenai manajemen event suatu perusahaan, penulis rasa penelitian kualitatif lebih efeketif digunakan. Sebab, dengan metode ini peneliti akan mendapatkan bukti-bukti empiris. Bukti empiris adalah bukti yang didapat dengan suatu cara atau metode melalui proses pengamatan oleh indera manusia.

Kemudian jenis studi kasus yang di pilih oleh peneliti adalah penelitian studi kasus Instrumental (instrumental case study) adalah penelitian studi kasus yang dilakukan dengan meneliti kasus untuk memberikan pemahaman mendalam atau menjelaskan kembali suatu proses generalisasi. Dengan kata lain kasus diposisikan sebagai sarana (instrumen) untuk menunjukan penjelasan yang mendalam dan pemahaman tentang sesuatu yang lain dari yang bisa dijelaskan. Melalui kasus yang diteliti, peneliti bermaksud untuk menunjukkan adanya sesuatu yang khas yang dapat dipelajari dari suatu kasus tersebut, yang berbeda dari penjelasan yang diperoleh dari objek-objek lainnya. [10].Alasan mengapa peneliti memilih jenis studi kasus instrumental yaitu karena, studi kasus instrumental adalah kasus khusus yang diuji untuk memberikan pemahaman yang mendalam tentang suatu masalah (issue) atau untuk memperbaiki teori yang telah ada. Walaupun studi kasus ini kurang di minati, ia memainkan peran yang mendukung, memfasilitasi pemahaman terhadap sesuatu yang lain (minat eksternal). Khususnya dilihat secara mendalam, dan konteksnya diteliti secara cermat, aktivitas-aktivitas untuk mendalami kasus tersebut dilakukan secara rinci, karena kasus ini membantu pemahaman tentang ketertarikan dari luar (minat eksrternal). Dasar pemilihan mendalami kasus ini dikarenakan kasus ini diharapkan dapat memperluas pemahaman peneliti tentang minat lainnya [10].

\section{HASIL PENELITIAN DAN PEMBAHASAN}

Bentuk usaha dalam meningkatkan customer engagement Dudimsum dalam meningkatkan 
impulsive buying adalah memanfaatkan dan memaksimalkan berbagai aspek dan strategi.

\section{Media Customer Engagement Dudimsum}

Media atau perantara dalam mendukung kegiatan customer engagement untuk meningkatkan impulsive buying pada brand Dudimsm adalah dengan menggunakan media sosial. Media adalah satu elemen penting dalam sebuah proses customer engagement dan impulsive buying, media yang potensial akan memaksimalkan proses customer engagement dan impulsive buying.

Dari hasil wawancara dengan owner Dudimsum yaitu Muhammad Bani Bastian, media sosial utama yang digunakan Dudimsum yakni media sosial Instagram. Instagram menjadi media yang potensial karna penyampaian atau penyebaran pesan yang berisi informasi kepada khalayak dapat diterima dengan cepat dan efektif. Bersifat dua arah, dimana komunikan dapat merespon informasi dan pesan yang disampaikan oleh komunikator melalui fitur- fitur di Intsagram. Karna Instagram dapat di akses kapan saja, dimana saja, bersifat komunikasi dua arah dan bersifat massal, maka Instagram adalah bagian dari komunikasi new media, tiga sifat utama yang menandai kehadiran teknologi komunikasi baru, yaitu interactivity, demassification, dan asynchronous. Interactivity merupakan kemampuan sistem komunikasi baru (biasanya berisi sebuah komputer sebagai komponennya) untuk berbicara balik (talk back) kepada penggunanya. Hampir seperti seorang individu yang berpartisipasi dalam sebuah percakapan. Dalam ungkapan lain, media baru memiliki sifat interaktif yang tingkatannya mendekati sifat interaktif pada komunikasi anatarpribadi secara tatap muka. Sifat kedua dari teknologi komunikasi baru adalah demassification atau yang bersifat massal. Maksudnya, kontrol atau pengendalian sistem komunikasi massa biasanya berpindah dari produsen kepada konsumen media. Sifat yang ketiga adalah asynchronous, artinya teknologi komunikasi baru mempunyai kemampuan untuk mengirimkan dan menerima pesan pada waktuwaktu yang dikehendaki oleh setiap individu peserta [11].

Hasil observasi dapat diketahui bahwa Instagram menjadi salah satu platform media sosial yang paling sering digunakan oleh berbagai kalangan, di Indonesia sendiri hingga bulan maret tahun 2021, Menurut data yang dirilis Napoleon Cat, Terdapat 87.340.000 pengguna Instagram di Indonesia, yang merupakan $31,7 \%$ dari seluruh populasi. Mayoritas dari mereka adalah wanita, yaitu $52,5 \%$. Orang yang berusia 18 sampai 24 adalah kelompok pengguna terbesar (32.000.000). Perbedaan tertinggi antara pria dan wanita terjadi pada orang yang berusia 13 hingga 17 tahun, di mana wanita memimpin sebanyak 2.200 .000

Dengan media yang potensial akan memaksimalkan kegiatan customer engagement dan juga akan memaksimalkan impulsive buying dengan ketertarikan pada postingan atau konten di media sosial Instagram Dudimsum. Dengan 
begitu memicu customer untuk melakukan pembelian impulsive. Menurut Herabadi, A G \& Verplanken, B, (2001) menyebutkan faktor yang memicu impulsive buying dapat berupa lingkungan toko (seperti penampilan produk,

cara dipamerkan, atau adanya fitur-fitur seperti bau yang harum, warna yang cantik, atau musik yang menyenangkan), faktor situasional (seperti ketersediaan waktu dan uang), dan faktor person-related (seperti pengalaman pendidikan, mood, identitas diri, dan kepribadian) [12]. Sihotang (2007) menyebutkan faktor-faktor yang mempengaruhi pembelian impulsive dapat berupa: (1) produk, seperti harga barang yang murah, kecilnya kebutuhan atau marginal, (2) pemasaran atau marketing, meliputi distribusi yang dilakukan dengan jumlah yang relatif banyak outlet yang self service, iklan melalui media massa yang sangat sugestibel, dan (3) karakteristik konsumen, seperti karakteristik atau kepribadian konsumen, jenis kelamin [13].

\section{Postingan Customer Engagement akun}

\section{Instagram Dudimsum}

Hasil dari pengumpulan data dapat diketahui bahwa postingan customer engagement yang dilakukan oleh brand Dudimsum dalam meningkatkan impulsive buying adalah dengan membuat konten dan program-program seperti pembaruan feed postingan maupun instastory, mengutamakan exposure produk atau menampilkan produk dengan tampilan yang menarik dan inovatif, informasi mengenai produk dan brand disajikan secara lengkap dan detail sehingga informasi mengenai brand Dudimsum dapat langsung terakses dengan mudah dan cepat. selain itu juga mengadakan promo-promo dan give away sehingga dapat meningkatkan penjualan sehingga customer tergiur dengan produk Dudimsum melalui konten dan program di Instagram.

Postingan konten-konten dan promo- promo Dudimsum melalui media sosial Instagram, mampu membantu memaksimalkan kegiatan customer engagement untuk mempengaruhi dan meningkatkan pembelian secara impulsif atau impulsive buying. Pemanfaatan media sosial Instagram disini juga menjadikan kepercayaan dan kenyamanan customer sebagai salah satu aset pada brand Dudimsum untuk mempromosikan brand Dudimsum, baik secara disadari maupun tidak. Postingan customer engagement akun Instagram Dudimsum pada penelitian ini mampu membuktikan bahwa media sosial khususnya Instagram dapat menjadi salah satu media untuk mengoptimalkan kegiatan customer engagement yang efektif sesuai dengan perkembangan teknologi digital saat ini.

Postingan menjadi hal yang sangat penting dalam proses customer engagement dan meningkatkan pembelian impulsif atau impulsive buying. Dalam buku Social Media Marketing The Next Generation of Social Engagement dijabarkan mengenai empat tahap proses engagement yang terdiri dari adanya interaksi dengan konsumen. Adapun keempat tahap tersebut adalah consumption, curation, creation, dan calaboration. (Evans, 2008) Pada proses customer engagement tahap consumption 
menjadi hal yang sangat penting dan harus diperhatikan, pada tahap consumption keterlibatan konsumen menjadi acuan untuk memulai aktifitas online yang terdiri dari kegiatan membaca, melihat, mendengar sebuah konten digital dan informasi dalam media social [14]. Informasi bisa berupa promosi atau informasi mengenai pengalaman dari pelanggan lain akan sebuah brand. Studi mengatakan bahwa pemicu utama seorang pelanggan termotivasi untuk terlibat dalam interaksi dengan sebuah perusahaan apabila mereka merasa mendapatkan informasi yang minim mengenai produk/jasa yang ditawarkan oleh sebuah perusahaan atau organisasi dan mereka menyadari kebutuhan akan penyelesaian masalah, memuaskan kebutuhan, atau mencari suatu informasi akan mendorong customer melakukan interaksi yang interaktif. Perusahaan dapat meposting hal-hal yang mampu memotivasi konsumen untuk membuat atau membagikan tips-tips, update menarik, konten-konten audio, foto, video, link dan sebaginya. Konten sosial inilah yang menjadi alat bagi pelanggan untuk melakukan interaksi yang interaktif dimana mereka bisa memberikan riview, rating, dan rekomendasi kepada pelanggan lain [15].

Pada tahap consumption peran postingan customer engagement pada brand adalah bagian penting dalam menarik perhatian customer untuk melakukan interaksi yang interaktif dengan brand Dudimsum, dimana ketika mereka merasa tertarik dan puas dengan sebuah konten, program, dan produk
Dudimsum, mereka bisa memberikan riview, rating, dan rekomendasi kepada pelanggan lain, bisa dengan langsung ataupun melalui media sosial. Menurut Sung Un Yang dan Minjeong Kang (2009) yang menjelaskan bahwa pengukuran konsep engagement di dalam sebuah blog sebagai kemungkinan dan hasil dari sebuah blog komunikasi yang interaktif dilakukan dengan mengukur variabel kognitif yang terdiri dari dimensi contingency interactivity, self-company connection, company attitude [16]. Pada postingan customer engagement akun Instagram Dudimsum harus mengacu pada elemen-elemen dimana responden mengalami ketertarikan saat membaca post-post didalam media online dengan tujuan menghasilkan sebuah komunikasi yang interaktif melalui media sosial Instagram, dengan mengukur variabel kognitif contingency interactivity.

Dimensi ini mengacu pada elemen- elemen dimana responden mengalami ketertarikan dalam membaca post-post di dalam media online. Pada penelitian yang dilakukan Sung Un Yang dan Minjeong Kang (2009) dalam menggunakan blog, elemen lain mengacu pada ketertarikan customer untuk terhubung langsung di dalam interaksi di dalam platform tersebut. Hal ini seiring dengan dimensi consumption yang juga melihat keterlibatan awal customer dari kegiatan membaca, menonton dan melihat sebuah konten digital dan informasi, dalam hal ini yang berada pada sebuah media sosial, dan dimensi curation dimana keterlibatan customer terlihat dari pemilihan, penyaringan, pemberian tanggapan, ataupun penggambaran konten yang ada yang bisa memotivasi customer lain dan 
menciptakan sebuah dialog atau forum mengenai sebuah produk atau perusahaan. Consumption dilihat dari bagaimana keterlibatan awal customer dalam mengonsumsi informasi dalam media sosial yang bisa berupa promosi, pengalaman dan curahan hati dari customer lain untuk dijadikan pertimbangan. Selain itu curation juga bisa dilihat dari aktivitas perusahaan dalam memilih dan menyeleksi konten digital yang digunakan untuk menyalurkan informasi yang berhubungan dengan mereknya. Konten-konten digital tersebut menjadi alat bagi customer untuk melakukan interaksi interaktif dimana mereka bisa memberikan riview, rating, dan rekomendasi kepada customer lain. Sehingga indikator yang dapat digunakan adalah customer tertarik untuk membaca, menonton, melihat sebuah informasi atau konten digital yang diposting oleh perusahaan. Setelah melihat postinganpostingan instastory yang ada pada fitur highlights di akun instagram @Dudimsum, customer Dudimsum memberikan testimoni mengenai produk, seperti rasa, ukuran dan penyajian, selain itu secara tidak langsung memberikan rekomendasi dan mempromosikan brand Dudimsum dengan cara bercerita tentang pengalaman setelah membeli produk Dudimsum, membagikan moment kebersamaan, kebahagiaan dan tidak sedikit yang memberikan ungkapan rasa puas terhadap brand Dudimsum pada postingan-postingan tersebut.

Setelah consumption adanya proses curation, curation adalah tahap kedua dari proses customer engagement dimana pelanggan akan memilih menyaring, memberi tanggapan, ataupun menggambarkan konten yang ada. Proses ini merupakan tindakan untuk memotivasi pelanggan lain dan menciptakan sebuah dialog atau forum mengenai sebuah produk atau perusahaan. Seperti yang sudah dijelaskan dalam tahap consumption, bahwa konten sosial mampu menjadi alat bagi pelanggan untuk melakukan interaksi yang interaktif dimana mereka bisa memberi riview, rating, dan rekomendasi kepada pelanggan lain yang memainkan peran langsung dalam menegaskan sebuah pembelian oleh pelanggan. Riview dan rating adalah metode pertama untuk meningkatkan pengalaman pembelian yang menunjukan apa yang disukai oleh customer, mengapa mereka menyukainya, atau mengapa mereka tidak menyukainya [14]. Konten-konten yang dibuat oleh customer Dudimsum pada media sosial Instagram bermanfaat bagi customer lain sebagai bahan pertimbangan dengan memberikan riview mengenai rasa, pelayanan, kenyaman, dan kesan setelah membeli produk Dudimsum, selain itu pemberian rating, rekomendasi atau ulasan evaluasi mampu memberikan informasi yang lebih baik mengenai suatu produk atau brand yang akan mempengaruhi keputusan customer lain untuk membeli produk Dudimsum melalui postingan pada media sosial Instagram.

Setelah tahap consumption dan curation akan menimbulkan tindakan yang sangat bermanfaat bagi brand Dudimsum, yaitu tahap creation, Implikasi di dalam tahap ini adalah ketika customer dengan segenap hati membagi pengalamannya dan mempublikasikan apa yang 
mereka lakukan, apa yang mereka bicarakan mengenai suatu merek atau perusahaan dengan harapan kontribusi yang mereka berikan bisa dilihat oleh suatu komunitas lain. Keterlibatan konsumen dalam tahap ini sangat bergantung pada penciptaan konten oleh perusahaan yang memotivasi anggota komunitas menanggapi, bertukar informasi, bertukar pengalaman, atau mendukung konten yang telah diciptakan. Dalam hal ini, keterlibatan yang dirasakan oleh pelanggan selama proses engagement di dalam komunitas akan menumbuhkan rasa empati, puas, percaya, rasa aman, dan sense-ofbelonging di dalam grup, serta dapat membangun hubungan yang kuat antar customer dengan saling membagi pengalaman dan informasi [15]. Dan tahap terakhir adalah colaboration, colaboration merupakan tahap terakhir dari proses customer engagement, collaboration adalah keterlibatan pelanggan dimana terjadi kolaborasi antara consumption, curation, dan creation yang dapat menciptakan sebuah aktivitas baru, misalnya ketika seseorang menonton sebuah video baru untuk dikonsumsi oleh anggota komunitas lain di dalam media sosial, hal ini akan makin membangun keterlibatan pelanggan lain semakin banyak.

Setelah melewati tahap creation pada proses customer engagement, selain akan menumbuhkan rasa empati, puas, percaya, rasa aman, dan sense-of-belonging pada brand Dudimsum, customer akan memberikan rekomendasi dengan membagikan pengalamannya dan mempublikasikan brand Dudimsum pada media sosial Instagram. Setelah tercapainya proses customer engagement diharapkan dapat memaksimalkan impulsive buying khususnya memaksimalkan tipe impulsive buying suggestion impulse, yaitu impuls saran dimana pembelian yang terjadi pada saat konsumen melihat produk Dudimsum dan merasa membutuhkannya hingga memutuskan untuk melakukan pembelian di Dudimsum. Setelah tipe suggestion impulse ada juga tipe reminder impulse, yaitu impuls pengingat merupakan pembelian yang terjadi karena konsumen tibatiba teringat untuk melakukan pembelian produk tersebut. Dengan demikian, konsumen telah pernah melakukan pembelian sebelumnya atau telah pernah melihat produk tersebut dalam iklan. Biasanya tipe ini didasari dorongan yang muncul saat melihat barang pada rak toko, display atau teringat informasi lainnya tentang suatu produk. Terakhir Planned impulse, impuls terencanca merupakan pembelian yang terjadi ketika konsumen memasuki toko dengan harapan melakukan transaksi pembelanjaan berdasarkan diskon, kupon, dan lain sebagainya tanpa merencanakan produk yang akan dibelinya. Konsumen juga membeli produk lain yang saat itu dijual dengan harga khusus discount atau cuci gudang, karena mengingat kebiasaan mengkonsumsi produk tersebut.

Hasil dari pengumpulan data penelitian pada informan kunci dan informan pendukung. Ratarata faktor customer melakukan impulsive buying selain melihat review, rating, dan rekomendasi, customer akhirnya memutuskan melakukan pembelian, karena melihat konten 
dan postingan yang menarik seperti menampilkan produk Dudimsum hingga konten promo diskon dan give away, dengan begitu customer merasa tergiur dan akhirnya memutuskan untuk membeli produk Dudimsum. Faktor marketing juga sangat berpengaruh dalam keputusan impulsive buying, dalam marketing hal yang mempengaruhi pembelian impulsive adalah distribusi massa, self-service outlet dan Ketersediaan informasi mengenai brand. Pemasangan iklan, barang yang dipamerkan, websites, penjaga toko, paket-paket, adanya discount, dan sumber yang bebas informasi konsumen menjadi daya tarik perilaku konsumsi impulsive buying mempengaruhi pembelian impulsive. Dalam hal ini menurut hasil pengumpulan data, Dudimsum selalu mengedepankan cita rasa dan pelayanan terbaik pada pembelian offline maupun online. Pada pembelian offline mengedepankan kebersihan pada outlet dan ramah pada customer. Pada pembelian online selalu berusaha memberikan pelayanan terbaik dari kualitas produk, packaging, pengiriman hingga sampai kepada pembeli. Selain itu informasi mengenai brand Dudimsum dapat di akses dengan mudah di website dan berbagai sosial media Facebook, Twitter dan Instagram. Dudimsum juga selalu memberikan konten yang menarik dan inovatif, mulai dari exposure produk hingga memberikan program give away dan diskon atau potongan harga, yang bertujuan untuk selalu memberikan inovasi-invoasi baru dengan maksimal pada customer
Dudimsum.

\section{Pelanggan Membuat Konten Tentang}

\section{Dudimsum Secara Sukarela}

Berdasarkan hasil wawancara mendalam dengan satu informan kunci dan lima informan pendukung. Menurut Muhammad Bani Bastian, Menjadi suatu kebanggaan bagi customer ketika mereka bisa makan di Dudimsum, karena Dudimsum selalu berusahamemberikan cita rasa dan pelayanan terbaik. Selain itu Dudimsum melakukan marketing-marketing yang inovatif dan menarik, seperti membuat salah satu varian produk menjadi limited edition, walaupun stock tersedia banyak tetapi dibuat menjadi limited edition, sehingga customer rela mengantri dan menunggu demi merasakan produk dari Dudimsum, ketika customer mendapatkan yang mereka inginkan, menjadi suatu kebanggan tersendiri bagi mereka. Langkah yang dirasa sangat berpangruh adalah Dudimsum berusaha semaksimal mungkin untuk selalu merespon dan merepost postingan atau instastory melalui Instagram, sehingga customer akan merasa di hargai. ketika brand merespon dan merepost segala bentuk konten ataupun pertanyaan melalui Instagram. Menjadi suatu kebanggan juga menurut Dudimsum untuk mereka, ketika apa yang mereka posting di repost oleh Dudimsum, yang notabene followers Dudimsum sudah lumayan banyak.

Elemen self-company connection merujuk pada kemampuan perusahaan merefleksikan customernya, kemampuan customer mengidentifikasi perusahaan dengan baik, adanya koneksi personal dengan perusahaan, penyebutan perusahaan (yang menggambarkan 
diri customer) ketika berinteraksi dengan customer lain, persepsi customer bahwa perusahaan bisa "membantu" mereka untuk menjadi pribadi yang mereka inginkan atau mampu menyelesaikan masalah mereka [17]. Elemen lain adalah customer menganggap perusahaan merefleksikan siapa dan apa yang sebenarnya customer inginkan atau bagaimana customer ingin menyatakan dirinya di depan customer lain, serta perasaan cocok dengan sebuah perusahaan atau merek tertentu. Lalu elemen ini juga mengacu pada kemampuan perusahaan memperlakukan customer secara baik, mampu memberikan penyelesaian masalah secara adil dan merujuk pada perlakuan customer secara hormat, dan perasaan bangga menjadi customer sebuah produk atau jasa atau perusahaan. Sehingga indikator dari dimensi ini mengacu pada perasaan customer bahwa perusahan mampu mengidentifikasi kebutuhan masalah konsumen dengan baik, mampu memberikan penyelesaian masalah, mampu memperlakukan customer secara memuaskan dan perasaan cocok yang muncul kepada suatu perusahaan atau merek tertentu.

Dengan usaha semaksimal mungkin yang dilakukan Dudimsum untuk selalu merespon dan merepost postingan atau instastory melalui Instagram, selain membuat customer merasa di hargai, menurut Brodi (2011) juga akan menumbuhkan rasa empati, puas, percaya, rasa aman, dan senseof- belonging terhadap brand Dudimsum, yang merupakan proses customer engagement yaitu creation, creation dalam bagian dari proses customer engagement, implikasi di dalam tahap ini adalah ketika customer dengan segenap hati membagi pengalamannya dan mempublikasikan apa yang mereka lakukan, apa yang mereka bicarakan mengenai suatu merek atau perusahaan dengan harapan kontribusi yang mereka berikan bisa dilihat oleh suatu komunitas lainnya [15]. Keterlibatan konsumen dalam tahap ini sangat bergantung pada penciptaan konten oleh perusahaan yang memotivasi anggota komunitas menanggapi, bertukar informasi, bertukar pengalaman, atau mendukung konten yang telah diciptakan. Dalam hal ini, keterlibatan yang dirasakan oleh pelanggan selama proses engagement di dalam komunitas akan menumbuhkan rasa empati, puas, percaya, rasa aman, dan sense-of- belonging di dalam grup, serta dapat membangun hubungan yang kuat antar customer dengan saling membagi pengalaman dan informasi. Dan tahap terakhir adalah colaboration, collaboration merupakan tahap terakhir dari keterlibatan pelanggan dimana terjadi kolaborasi antara consumption, curation, dan creation yang dapat menciptakan sebuah aktivitas baru, misalnya ketika seseorang menonton sebuah video baru untuk dikonsumsi oleh anggota komunitas lain di dalam media sosial, hal ini akan makin membangun keterlibatan pelanggan lain semakin banyak.

Indikator customer engagement Extraversion menurut Zuckerman dalam Aluja Garcia \& Garcia (2003) extraversion, dimensi ini merujuk pada sikap asertif sosial, aktifitas yang kuat, dan efek positif. Extraversion berhubungan erat dengan sikap petualang, aktif, dan keluar dari 
sikap atau pemikiran yang ada. Dalam dimensi ini bisa diperoleh jika customer mendapatkan berbagai variasi dan dengan intensitas sensasi yang dihasilkan dan mempengaruhi sikap mereka. Pencarian sensasi dimengerti sebagai pencarian sensasi atau pengalaman yang kompleks, baru dan bervariasi dan kesediaan untuk mengambil resiko dari pengalaman itu. Extraversion secara signifikan mengacu pada pencarian sensasi itu. Sehingga dalam hal ini, indikator yang bisa digunakan untuk mengukur dimensi extraversion adalah sikap asertif customer untuk melihat, membaca atau mengunduh konten-konten digital di dalam dalam platform dan sikap asertif customer dalam memberikan tanggapan atau komen, like, repost ataupun mengupload konten terkait brand tersebut. Setelah inditakor extraversion adalah indicator opennes the experience, dimensi ini merujuk pada pencapaian intelektual, emosional, behavioral dan pengalaman estetis. Opennes the experience juga berhubungan dengan sikap kreatif, imajinatif, dan terbuka untuk ide-ide baru dan perubahan. Indikator yang digunakan antara lain sikap mau mengadopsi akan ide-ide atau tips-tips yang diberikan oleh brand dan sikap menerima terhadap sebuah produk dengan konsep ataupun kegunaan yang lebih baru (tidak biasa/orisinil) [18].

Indikator terakhir dari customer engagement adalah behavioral attachment, behavioral attachment adalah perilaku atau partisipasi customer di dalam sebuah upaya engagement sebuah perusahaan atau merek adalah harapan tertinggi yang mampu membawa perubahan perilaku atau memotivasi perilaku customer lain. Partisipasi customer dalam aktivitas online dengan melaporkan aktivitasaktivitas offline yang berhubungan dengan sebuah merek atau perusahaan akan menampilkan dimensi perilaku dari keterlibatan customer secara positif. Keterlibatan ini harus mampu menyediakan dukungan sosial kepada merek atau perusahaan (bila proses keterlibatan yang muncul bersifat positif) atau jika tidak justru menghasilkan efek negatif yaitu kritik terhadap merek atau perusahaan, rekomendasi menyesatkan, tidak direkomendasikannya sebuah merek atau perusahaan tertentu. Sehingga variabel perilaku adalah variabel terakhir yang digunakan untuk mengukur sebuah merek atau perusahaan dalam konteks customer engagement. Adapun variabel ini terdiri dari beberapa dimensi seperti

\section{a. Company behaviour}

Dimensi ini adalah gabungan dari konsep company attitude dengan konsep creation yang merujuk pada kemampuan perusahaan untuk menciptakan konten yang mampu memotivasi customer untuk berinteraksi. Sehingga indikator yang bisa digunakan adalah kemampuan perusahaan menciptakan konten-konten yang interaktif dan kemampuan perusahaan menunjukkan reputasi yang baik.

\section{b. Customer behaviour}

Jika pada konsep word-of-mouth, customer secara sukarela akan mempromosikan, merekomendasi dan mengatakan hal positif pada customer lain, maka sudah mencapai tahap tertinggi dari customer engagement yang didasari penuh oleh kepercayaan. Sehingga 
indikator yang digunakan adalah kemauan customer secara sukarela merekomendasi merek dan membagikan pengalaman positif. Menurut hasil dari pengumpulan data, Dudimsum selalu berusaha merespon customer, baik itu me repost ataupun merespon melalui comment dan direct message di Instagram Dudimsum. Dudimsum juga sering memberikan atau mengadakan konten-konten yang interaktif, seperti berkomunikasi dan berinteraksi dengan customer menggunakan fitur poling, saran, pertanyaan seputar keinganan dan pendapat customer mengenai brand pada Instagram atau secara langsung, selain itu Dudimsum memberikan konten promo dan give away untuk mempertahankan dan menjaga hubungan dengan customernya. Dengan begitu customer akan merasa lebih di hargai dan dianggap. Setelah memiliki hubungan yang baik dengan customernya, customer akan memberikan feedback yang sangat bermanfaat bagi brand, seperti salah satu contohnya customer memberikan rekomendasi dan mempromosikan brand Dudimsum secara sukarela melalui media sosial ataupun secara langsung dari mulut ke mulut.

\section{PENUTUP}

\section{Kesimpulan}

Berdasarkan hasil penelitian mengenai customer engagement akun instagram dalam meningkatkan impulsive buying pada brand Dudimsum dikota Bandung, Maka peneliti dapat menyimpulkan beberapa hal sesuai permasalahan dan tujuan penelitian.
Kesimpulan yang di peroleh pada penelitian ini diantaranya:

1. Media customer engagement yang digunakan Dudimsum dalam meningkatkan impulsive buying yakni media sosial Instagram. Instagram menjadi media yang potensial karna Instagram adalah bagian dari komunikasi new media, dengan menggunakan media sosial Instagram penyampaian atau penyebaran pesan yang berisi informasi mengenai brand kepada khalayak dapat diterima dengan cepat dan efektif. Instagram dapat di akses kapan saja, dimana saja, bersifat massal dan bersifat komunikasi dua arah, dimana customer dapat merespon langsung informasi dan pesan yang disampaikan oleh Dudimsum melalui Intsagram. Instagram menjadi salah satu platform media sosial yang paling sering digunakan, Indonesia termasuk dalam lima negara pengguna Instagram terbanyak. Hingga bulan maret tahun 2021, Menurut data yang dirilis Napoleon Cat, Terdapat 87.340 .000 pengguna Instagram di Indonesia, yang merupakan $31,7 \%$ dari seluruh populasi. Mayoritas dari mereka adalah wanita, yaitu $52,5 \%$. Orang yang berusia 18 sampai 24 adalah kelompok pengguna terbesar (32.000.000). Perbedaan tertinggi antara pria dan wanita terjadi pada orang yang berusia 13 hingga 17 tahun, di mana wanita memimpin sebanyak

2. 2.200.000. Berikut grafik pengguna aktif media sosial Instagram di Indonesia pada bulan maret 2021 .

3. Postingan customer engagement di 
Instagram Dudimsum dalam meningkatkan impulsive buying, konten dan program- program pembaruan feed postingan dan instastory, mengutamakan exposure produk atau menampilkan produk dengan tampilan yang menarik dan inovatif, informasi mengenai produk dan brand disajikan secara lengkap dan detail sehingga informasi mengenai brand Dudimsum dapat langsung terakses dengan mudah dan cepat. selain itu juga mengadakan promopromo dan give away sehingga dapat meningkatkan penjualan dengan membuat customer tergiur terhadap produk Dudimsum melalui konten dan program di Instagram. Postingan konten- konten dan promo-promo Dudimsum melalui media sosial Instagram, mampu membantu memaksimalkan kegiatan customer engagement untuk mempengaruhi dan meningkatkan pembelian secara impulsif atau impulsive buying. Pemanfaatan media sosial Instagram menjadikan kepercayaan dan kenyamanan customer sebagai salah satu aset pada brand Dudimsum untuk mempromosikan brand Dudimsum, baik secara disadari maupun tidak. Postingan customer engagement akun Instagram Dudimsum pada penelitian ini mampu membuktikan bahwa media sosial khususnya Instagram dapat menjadi salah satu media untuk mengoptimalkan kegiatan customer engagement yang efektif sesuai dengan perkembangan teknologi digital saat ini.

4. Pelanggan Dudimsum bersedia membuat konten di Instagram @Dudimsum dengan sukarela, menurut hasil pengumpulan data penelitian. Dudimsum selalu berusaha memberikan cita rasa dan pelayanan terbaik. Dudimsum berusaha semaksimal mungkin untuk selalu merespon dan merepost postingan atau instastory melalui Instagram, sehingga customer akan merasa di hargai. Menjadi suatu kebanggan juga menurut Dudimsum untuk mereka, ketika apa yang mereka posting di repost oleh Dudimsum, yang notabene followers Dudimsum sudah lumayan banyak. Dudimsum selalu berusaha merespon customer, baik itu me repost ataupun merespon melalui comment dan direct message di Instagram Dudimsum. Dudimsum juga sering memberikan atau mengadakan konten-konten yang interaktif, seperti berkomunikasi dan berinteraksi dengan customer menggunakan fitur poling, saran, pertanyaan seputar keinganan dan pendapat customer mengenai brand pada Instagram atau secara langsung, selain itu Dudimsum memberikan konten promo dan give away untuk mempertahankan dan menjaga hubungan dengan customernya. Dengan begitu customer akan lebih merasa di hargai dan dianggap. Setelah memiliki hubungan yang baik dengan customernya, customer akan memberikan feedback yang sangat bermanfaat bagi brand, seperti salah satu contohnya customer memberikan 
rekomendasi dan mempromosikan brand Dudimsum secara sukarela melalui media sosial ataupun secara langsung dari mulut ke mulut.

\section{Rekomendasi}

Adapun rekomendasi berdasarkan hasil penelitian mengenai customer engagement akun instagram dalam meningkatkan impulsive buying pada brand Dudimsum dikota Bandung, Maka peneliti memberikan rekomendasi atau saran untuk kebaikan brand kedepennya, diantaranya:

1. Penggunaan media customer engagement Dudimsum lebih di explore untuk update platform media yang lebih potensial pada saat ini, seperti tiktok dan youtube untuk memaksimalkan dan meningkatkan impulsive buying.

2. Penjadwalan postingan customer engagement di Instagram Dudimsum dilakukan dengan konsisten dan perjadwal yang terstruktur untuk konten setiap harinya.

3. Melakukan pembaruan terhadap desain konten yang lebih menarik dan eyecathing, konten dan program yang lebih inovatif agar customer Dudimsum tertarik untuk membuat konten atau merekomendasikan brand Dudimsum di Instagram dengan sukarela.

\section{DAFTAR PUSTAKA}

[1] Tripathi, M. N. (2009). Customer Engagement - Key to Successful Brand Building. Vilakshan: The
XIMB Journal of Management.

[2] Sanaji, Evi Rahmati. 2015. "Pengaruh Customer Engagement Terhadap Kepuasan Pelanggan Dan Kepercayaan Merek Serta Dampaknya Pada Loyalitas Merek". Jurnal Riset Ekonomi dan Manajemen.Vol 15, No.2. 1-16.

[3] Paulson, Dans. (2009). I'm Happy to be Here - How Engaged Employees Improve Your Bottom Line.

[4] Alexander, dan Jaakkola. (2015). Customer Engagement Behaviours and Value Co-creation. A book chapter intended for Customer Engagement: Contemporary Issues and Challenges.

[5] Abbas, A.K., Aster, J.C., dan Kumar, V. 2015. Buku Ajar Patologi Robbins. Edisi 9. Singapura: Elsevier Saunders.

[6] Ryan, Damian., \& Jones, Calvin. (2009). Understanding Digital Marketing: Marketing Strategies for Engaging The Digital Generation. United States: Kogan Page Limited.

[7] Moleong, j, Lexy. 2006. Metodologi Penelitian Kualitatif. Bandung: PT. Remaja Rosdakarya.

[8] Sujarweni, V. Wiratna. 2014. Metode Penelitian: Lengkap, Praktis, dan Mudah Dipahami. Yogyakarta: Pustaka Baru Press.

[9] Nursalam. 2016. Metodologi Penelitian Ilmu Keperawatan Pendekatan Praktis Edisi.4. Jakarta : Salemba Medika.

[10] Alif, Gunawan. 2013. Komunikasi Interpersonal Dan Fasilits Kesehatan: Pengaruhnya Terhadap Kepercayaan, Loyalitas Dan Wom Rumah Sakit. (Online).Vol 1, No 3; Oktober 2013. ISNN: 2302-4119. Diakses 6 Juli 2014.

[11] Hamidati, Anis, dkk. 2011. Komunikasi 2.0 Teoritisasi dan Implikasi. Yogyakarta: Mata Padi Pressindo

[12] Herabadi, A.G. (2003). Buying Impulses - A Study on Impulsive Consumption. 
Doctoral Thesis; University of Nijmegen.

[13] A. Sihotang, 2007, Manajemen Sumber Daya Manusia, Cetakan Pertama, PT Pradnya Paramitha, Jakarta.

[14] Evans, Dave. (2008). Social Media Marketing. Indiana: Wiley Publishing

[15] Brodie, Roderick J., et al. (2011). Consumer Engagement in A Virtual Brand Community: An Exploratory Analysis. Elsevier, Inc: New Zealand
[16] Yan, Sun Un \& Minjeong Kang. 2008. Measuring Blog Engagement: Testing a Four Dimensional Scale. Journal of Market Focused Management.

[17] Moore, D. J., \& Homer, P. M. (2008). Self-brand connections: the role of attitude strength and autobiographical memory primes. Journal of Business Research, Vol. 61 No. 7, 707-714.

[18] Aluja, A., Garcia, O., \& Garcia, C. (2003). Relationships Among Extraversions, Opennes to Experience, and Sensation Seeking. Personality and Individual Differences. 